\title{
HUBUNGAN KEMATANGAN BERAGAMA DENGAN KARAKTER $A L$-HIRS MAHASISWA PGMI FAKULTAS TARBIYAH IPMAFA PATI
}

\author{
Mohamad Agus Jauhari \\ Latifah Nuraini, M. Sofyan Alnashr \\ Prodi Pendidikan Guru Madrasah Ibtidaiyah \\ Fakultas Tarbiyah dan Keguruan \\ Institut Pesantren Mathaliul Falah Pati Jawa Tengah \\ jauhari@ipmafa.ac.id
}

\begin{abstract}
Abstrak
Penelitian ini bertujuan mengetahui hubungan kematangan beragama dengan karakter Al Hirș mahasiswa Program Studi PGMI Fakultas Tarbiyah IPMAFA Pati Tahun 2019. Penelitian ini merupakan penelitian diskriptif kuantitatif dengan desain penelitian korelatif yang menghubungkan dua variabel, yaitu kematangan beragama sebagai variabel bebas dan karakter Al Hirs sebagai variabel terikat. Subjek penelitian adalah mahasiswa Program Studi PGMI IPMAFA sebanyak 241 mahasiswa dan diambil sampel 24 mahasiswa. Teknik analisis data yang digunakan adalah dengan analisis korelasi product moment. Berdasarkan hasil analisis data diperoleh bahwa terdapat hubungan positif antara kematangan beragama dengan karakter al Hirș. Hal ini ditunjukkan dengan nilai $r$ hitung lebih besar dari $r$ tabel $(0,416>0,4044)$ dan nilai signifikansi 0,043 lebih kecil dari 0,05. Kematangan agama dan karakter al Hirș mahasiswa PGMI yang baik berdampak pada sikap disiplin mahasiswa mengikuti pembelajaran dan diskusi di kelas. Dua hal ini juga menjadi elemen penting bagi pengembangan diri mahasiswa PGMI.
\end{abstract}

Kata kunci: Kematangan Beragama, Karakter Al Hirș, mahasiswa PGMI

Abstract

This study aims to determine the relationship between religious maturity and the character of Al Hirs students on PGMI Faculty of Tarbiyah IPMAFA Pati in 2019. This research is a quantitative descriptive study with a correlative research design that connects two variables, namely religious maturity as an independent variable and Al Hirs character as a dependent variable. The research subjects were 241 students of PGMI IPMAFA Study Program and 24 students were sampled. The data analysis technique used is product moment correlation analysis. Based on the results of data analysis, it is found that there is a positive relationship 
between religious maturity and the character of Al Hirș. This is indicated by the calculated $r$ value greater than $r$ table $(0.416>0.4044)$ and a significance value of 0.043 less than 0.05 . Religious maturity and character of al Hirș PGMI students has an impact on the discipline of students following learning and discussion in class. These two things also become important elements for the development of PGMI students themselves.

Keyword: Mature Religion, Character of Al Hirș, students of PGMI

\section{A. PENDAHULUAN}

Institut Pesantren Mathali'ul Falah (IPMAFA) Pati menjadi salah satu perguruan tinggi yang secara eksplisit dan legal formal menyematkan kata pesantren. Hal ini menjadi pembeda IPMAFA dengan perguruan tinggi lain sekaligus menjadi ciri khas utama di mana kampus terintegrasi dengan pesantren. Kiai Sahal Mahfudh menjelaskan bahwa STAIMAFA-IPMAFA bukanlah perguruan tinggi yang didirikan oleh pesantren melainkan perguruan tinggi yang berbasis nilai-nilai pesantren. Nilai-nilai pesantren yang menjadi basis kampus tersebut pada akhirnya dirumuskan sebagai Nilai Dasar Shalih Akram (NDSA) yakni nilai 9+1.

Salah satu nilai dari NDSA sebagaimana terangkum dalam Statuta IPMAFAialah Al-Hirș (curiousity) yaitu kecintaan dan keingintahuan terhadap ilmu dan pengetahuan yang tinggi sehingga menjadi motivasi belajar yang tidak terkikis waktu dan usia. Nilai tersebut merupakan landasan pokok bagi mahasiswa IPMAFA dalam menuntut ilmu. Rasa cinta akan ilmu akan mampu memberikan motivasi kuat untuk terus mencari ilmu dan selalu merasa bodoh sehingga akan terus belajar. Belajar dalam pandangan Islam bukan hanya sekedar di lembaga pendidikan formal namun berjalan sepanjang hayat sejak lahir hingga meninggal dunia. Maka dari itu, lembaga pendidikan masyarakat termasuk pondok pesantren haruslah bersifat fungsional ${ }^{1}$, sebab lembaga pendidikan sebagai salah satu wadah dalam

${ }^{1}$ A. Zaenurrosyid, Pengaruh Pondok Pesantren terhadap Kehidupan Sosial Masyarakat Desa Kajen Kec. Margoyoso Kab. Pati, Islamic Review: Jurnal Riset dan Kajian Keislaman, Vol. VII No. 1 Tahun 2018, hlm. 55-71, DOI: https://doi.org/10.35878/islamicreview.v7i1.133 
masyarakat biasa dipakai sebagai pintu gerbang dalam menghadapi tuntutan masyarakat, ilmu pengetahuan dan teknologi yang terus mengalami perubahan.

Meskipun setiap individu hidup dan berkembang dalam suatu tatanan nilai yang sama dalam masyarakat maupun agama, namun setiap individu tidak akan memiliki kesamaan sikap dan perilaku. Faktor internal individu juga berperan penting dalam pembentukan karakter individu. Salah satu faktor dalam diri individu yang berperan penting dalam menjalani aktivitas ialah kecerdasan. ${ }^{2}$ Melalui kecerdasan pada akhirnya manusia mampu membangun dan mengembangkan budaya dan peradabannya. Kecerdasan tersebut menjadi awal berkembangnya pemahaman hingga menjadi sebuah kematangan dalam diri seseorang.

Hal ini juga berlaku dalam beragama, yang lebih condong pada perkembangan rohani sehingga puncaknya ialah sebuah kematangan. Agama merupakan sebuah kepercayaan subjektif dengan ritual dan ajaran yang dianutnya. ${ }^{3}$ Inti dari kepercayaan agama ialah Tuhan yang transenden, yang Sakral, yang Suci. Pada hakikatnya, agama mengajarkan manusia untuk berbuat baik dan mengakui kebesaran Zat Transenden. Kepercayaan kepada Tuhan tersebut menjadikan manusia sebagai penganut ajaran agama serta semua ritual keagamaan yang bersumber dari Kitab Suci dan disampaikan melalui Nabi dan Rasul. Ajaran agama kemudian berkembang dan diikuti secara turun-temurun.

Menurut James, agama memiliki peranan sentral dalam menentukan perilaku manusia. ${ }^{4}$ Pengetahuan, pemahaman, dan implementasi dari ajaran agama turut membentuk sikap dan karakter manusia. Akan tetapi, memahami ajaran agama secara komprehensif bukanlah perkara mudah. Dalam Islam misalnya, ajaran Islam tidak bisa dipahami hanya dengan membaca sumber utamanya yaitu Alquran dan Hadits

${ }^{2}$ Asrul Faruq dan M. Sofyan Alnashr, Implementasi Strategi Pembelajaran Edupreneurship Berbasis Multiple Intelligences, Islamic Review: Jurnal Riset dan Kajian Keislaman, Vol. 6 No. 2 Th. 2017, hlm. 195-210, DOI: https://doi.org/10.35878/islamicreview.v6i2.129

${ }^{3}$ Jalaluddin Rakhmat, Psikologi Agama; Sebuah Pengantar, Bandung: Mizan, 2003, hlm. 34

${ }^{4}$ Wiliam James, The Varieties of Religious Experience: A Study in Human Nature, New York: Modern Library, 1958, hlm. 59 
saja, tetapi dibutuhkan berbagai disiplin ilmu untuk mengetahui dan menginterpretasi ajaran agama Islam yang mendekati kebenaran.

Hadirnya agama memiliki dua pesan pokok, yaitu mengajarkan manusia supaya mempunyai visi serta makna hidup yang bersumber dari iman dan menjadikan manusia sebagai pribadi yang baik melalui pemahaman dan penghayatan agama. ${ }^{5}$ Pemahaman dan penghayatan akan ajaran agama yang baik akan membawa seseorang pada keadaan rohani yang mantap atau biasa disebut dengan kematangan beragama.

Kematangan beragama tidak bisa dicapai tanpa memiliki kecerdasan dalam memahami ajaran agama, menghayati, dan mempraktikkannya hingga menjadi sebuah karakter. Kematangan beragama tidak ditunjukkan oleh usia melainkan pemahaman dan praktik keagamaan. Pada kenyataannya masih banyak manusia yang dewasa secara usia namun perilaku keagamaannya ritualistik dan superfisial (rutinitas ritual karena kebiasaan dan tanpa memahami maknanya). ${ }^{6}$

Kematangan beragama inilah yang diharapkan dimiliki oleh mahasiswa IPMAFA mengingat basis aktivitasnya ialah nilai-nilai pesantren. Salah satu ciri dari kampus pesantren ialah budaya belajar yang giat dan ibadah yang baik. Tak terkecuali mahasiswa Program Studi Pendidikan Guru Madrasah Ibtidaiyah (PGMI) Fakultas Tarbiyah IPMAFA Pati. Mahasiswa yang disiapkan untuk menjadi pendidik profesional pada jenjang pendidikan dasar Islam (MI) dan pendidikan dasar umum (SD) yang shalih akram. Maka pengetahuan, pemahaman, dan penghayatan ajaran agama Islam wajib dikuasai oleh mahasiswa PGMI.

Fakta di lapangan menunjukkan masih terdapat mahasiswa PGMI yang bukan hanya tidak memahami bahkan belum mengetahui ajaran dasar dari agama Islam seperti syarat rukun shalat, wudlu, zakat, dan pengetahuan dasar lainnya dengan

\footnotetext{
83

${ }^{5}$ Komaruddin Hidayat, Agama Punya Seribu Nyawa, cet. II, Jakarta: Noura Books, 2012, hlm.

${ }^{6}$ Jejen Musfah, Pendidikan Holistik: Pendekatan Lintas Perspektif Islam, Jakarta: Kencana, 2012, hlm. 258
} 
baik. ${ }^{7}$ Hal ini diketahui berdasarkan observasi di kelas PGMI dan diperkuat laporan dari beberapa dosen yang mengkhawatirkan pengetahuan mahasiswa atas ajaran dasar agama Islam. Di sisi lain, terdapat pula mahasiswa dengan pengetahuan dan pemahaman keagamaan yang baik, beberapa di antaranya berprestasi secara akademik maupun non akademik.

Hal yang menjadi pertanyaan ialah apakah kematangan beragama ada kaitannya dengan kecintaan pada ilmu, prestasi akademik, dan literasi mahasiswa PGMI? Hal ini kemudian yang menjadi dasar pertimbangan dilakukannya penelitian terhadap kematangan beragama mahasiswa PGMI dalam hubungannya dengan karakter Al-Hirș (kecintaan terhadap ilmu).

Untuk melihat posisi penelitian ini terhadap penelitian dengan tema yang sama, perlu dijelaskan perbedaan antar penelitian. Beberapa penelitian yang patut dijadikan kajian antara lain penelitian Yulika dan Setiawan bahwa ada hubungan positif yang sangat signifikan antara kematangan beragama dengan perilaku pacaran pada santri MA Pondok Pesantren Modern Al-Furqon Prabumulih. ${ }^{8}$ Hasil analisis yang diperoleh koefisien korelasi sebesar $\mathrm{R}=0,764$ dengan signifikansi $0,000 \mathrm{p}<0,01$ sehingga diketahui remaja yang menjalankan keagamaan tanpa perasaan dan penghayatan cenderung tidak akan bermanfaat sebagai pengontrol perilaku pacaran.

Penelitian lain oleh Wahyuni ${ }^{9}$ mencoba mencari hubungan kematangan beragama dengan konsep diri mahasiswa. Hasil penelitian hubungan antara variabel kematangan beragama dan konsep diri ditunjukkan dengan koefisien Rxy $=0,059$ dengan $p<0,589$ dengan arah hubungan positif yang menunjukkan semakin tinggi

${ }^{7}$ Hal ini terkuak saat agenda rapat dosen PGMI berkaitan dengan kemampuan mahasiswa PGMI dalam menjalankan ajaran dasar agama Islam seperti membaca Alquran, praktik wudlu, atau shalat. Ternyata terdapat beberapa mahasiswa yang masih salah dalam wudlu dan tidak lancar bacaan al-Qur'annya.

${ }^{8}$ Apni Yulika, dan Kiki Cahaya Setiawan, Kematangan Beragama dengan Perilaku Pacaran pada Santri MA di Pondok Pesantren Modern Al-Furqon Prabumulih, Jurnal Psikologi Islami, Vol. 3 No. 1 Tahun 2017, hlm. 60-69

9 Wahyuni, Ida Windi, Hubungan Kematangan Beragama dengan Konsep Diri, Jurnal Al-Hikmah, Vol. 8 No. 1, Tahun 2011, hlm. 1-8 
kematangan beragama maka semakin tinggi pula konsep dirinya, begitu juga sebaliknya.

Selanjutnya penelitian yang dilakukan Rizqiyah tentang kematangan beragama orang tua yang berusia 40-49 tahun dalam pembinaan akhlaq anak. Hasil penelitian menunjukkan bahwa orang tua yang matang beragama di usianya 40-49 tahun, cerdas dalam membina akhlaq anak. Kematangan beragama orang tua yang berusia 40-49 tahun dalam membina akhlaq anaknya dapat dilihat dari perilaku anak yang sesuai dengan ajaran agama yang telah ditanamkan orang tua sejak kecil hingga dewasa. ${ }^{10}$

Berbeda dengan beberapa penelitian di atas, penelitian yang dilakukan peneliti mencoba melihat hubungan kematangan beragama dengan karakter Al-Hirș mahasiswa PGMI Fakultas Tarbiyah IPMAFA Pati. Orisinalitas penelitian ini terlihat dari kajian tentang NDSA khususnya nilai Al-Hirș yang merupakan prinsip dasar IPMAFA dalam menyiapkan insan yang shalih dan akram. Penelitian dengan topik ini belum pernah dilakukan sebelumnya sehingga layak untuk dikaji lebih dalam.

\section{B. METODE PENELITIAN}

Penelitian ini merupakan penelitian diskriptif kuantitatif dengan desain penelitian korelatif yang bermaksud menjelaskan hubungan kematangan beragama dengan karakter Al-Hirș mahasiswa PGMI Fakultas Tarbiyah IPMAFA Pati. Desain penelitian yang digunakan dalam penelitian ini termasuk jenis korelasional karena penelitian mencari ada tidaknya hubungan antara satu variabel dengan variabel yang lain. Penelitian ini dilakukan di Institut Pesantren Mathali'ul Falah (IPMAFA) Pati dengan subjek penelitian mahasiswa prodi PGMI Fakultas Tarbiyah yang aktif tahun akademik 2018/2019 dengan sampel yang diambil sebanyak 24 mahasiswa. Penelitian ini menggunakan dua variabel, yaitu: (1) variabel bebas pada penelitian ini adalah kematangan beragama mahasiswa PGMI Fakultas Tarbiyah IPMAFA, (2)

${ }^{10}$ Umi Rizqiyah, Analisis Kematangan Beragama Orang Tua yang Berusia 40-49 Tahun dalam Pembinaan Akhlaq Anak (Studi Kasus di Lingkungan Masyarakat Desa Grogol Kec. Dukuhturi Kab. Tegal), Skripsi, (Semarang: FITK UIN Walisongo, 2017) 
variabel terikat penelitian ini yaitu karakter Al-Hirș mahasiswa PGMI Fakultas Tarbiyah IPMAFA Pati.

Rancangan penelitian ini adalah penelitian deskriptif kuantitatif dengan jenis penelitian korelasional. Pengumpulan data dilakukan melalui penyebaran angket tertutup kepada mahasiswa PGMI IPMAFA Fakultas Tarbiyah yang aktif tahun 2018/2019, yaitu pada bulan Juli - Agustus 2019. Untuk menilai kematangan beragama dan karkater Al-Hirș maka digunakan angket dengan memakai skala likert dengan modifikasi 4 skala. Penggunaan 4 skala ini untuk mengetahui tingkat kematangan beragama dan bagaimana karakter Al-Hirș dengan kategori: sangat matang/sangat baik, matang/baik, kurang matang/kurang baik, dan tidak matang/tidak baik. Pengembangan instrumen didasarkan pada kerangka teori yang telah disusun selanjutnya dikembangkan dalam indikator-indikator dan dijabarkan dalam bentuk pertanyaan.

Dilakukan satu kali uji coba instrumen angket terhadap 13 mahasiswa, kemudian data dianalisis untuk mengetahui tingkat validitas dan reliabilitas. Setelah angket valid kemudian angket siap diujikan dan dilakukan analisis data. Angket dikonsultasikan dan direvisi agar redaksi yang digunakan sesuai dengan teori. Dengan melalui tahapan tersebut, angket telah melalui validasi isi. Uji validitas dilaksanakan dengan rumus korelasi dari Pearson yang dikenal dengan Korelasi Product Moment. Reliabilitas instrumen dalam penelitian ini menggunakan rumus Alpha. ${ }^{11}$ Reliabilitas dalam penelitian ini menggunakan SPSS versi 15.0 dengan menghitung besarnya nilai Cronbach's Alpha dari variabel yang diuji. Apabila nilai lebih besar dari 0,600 maka dinyatakan reliabel.

\footnotetext{
${ }^{11}$ Suharsimi Arikunto, Prosedur Penelitian Suatu Pendekatan Praktik, Jakarta: Rineka Cipta, 2014, hlm. 196
} 


\section{HASIL DAN PEMBAHASAN}

\section{Hasil Penelitian}

\section{a. Kematangan Beragama}

Berdasarkan penggalian data yang dilakukan terhadap 24 mahasiswa PGMI Fakultas Tarbiyah IPMAFA Pati dengan menggunakan angket tertutup, terdapat data tentang kematangan beragama mahasiswa PGMI. Dari data tersebut sebanyak 20 mahasiswa termasuk dalam kategori matang dan sangat matang. Sementara 4 mahasiswa termasuk kurang matang ( 3 orang) dan hanya 1 orang yang tidak matang dalam beragama.

Data ini menunjukkan bahwa tingkat kematangan beragama mahasiswa PGMI tinggi atau rata-rata mahasiswa PGMI matang dalam beragama. Meskipun masih terdapat seorang yang tidak matang dalam beragama serta tiga mahasiswa lainnya kategori kurang matang.

Hasil persentase terhadap kematangan beragama 24 mahasiswa PGMI tersebut disajikan dalam gambar berikut:

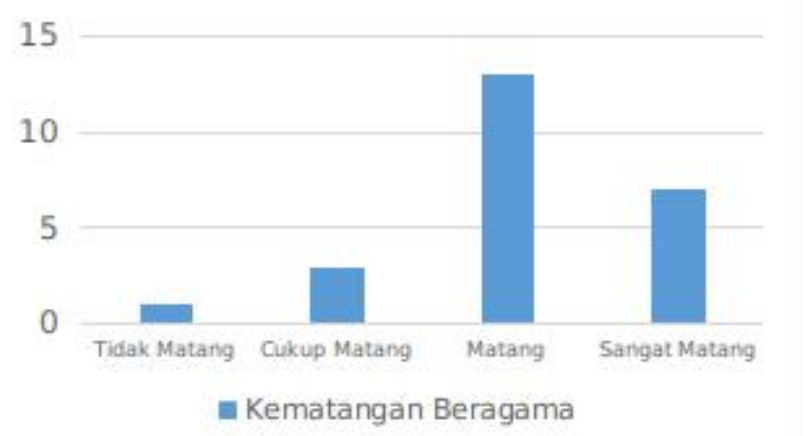

Gambar 1 Persentase kematangan beragama mahasiswa PGMI Fakultas Tarbiyah IPMAFA

Kemampuan seseorang untuk mengenali atau memahami nilai agama yang terletak pada nilai-nilai luhurnya serta menjadikan nilai-nilai dalam bersikap dan bertingkah laku merupakan ciri dari kematangan beragama. Keyakinan akan ditampilkan dalam sikap dan tingkah laku keagamaan yang 
mencerminkan ketaatan terhadap agamanya. ${ }^{12}$ Selain itu kematangan akan membawa seseorang pada ketenangan dalam menghadapi segala sesuatu.

\section{b. Karakter Al-Hirș}

Mahasiswa dengan karakter Al-Hirș yang baik akan tumbuh menjadi mahasiswa yang aktif dalam kegiatan akademik. Sebagai mahasiswa, karakter ini sangat dibutuhkan untuk menumbuhkan motivasi menuntut ilmu dan memiliki cita-cita yang tinggi. Rasa cinta akan ilmu akan membawa mahasiswa meraih nilai akademik yang baik yang sangat penting bagi mahasiswa. Al-Hirș adalah rasa ingin tahu dan kecintaan terhadap ilmu. Karakter Al-Hirș berarti sikap dan perilaku mahasiswa yang menunjukkan seberapa besar kecintaan mereka terhadap ilmu.

Data hasil penelitian memberikan gambaran bahwa karakter Al-Hirș mahasiswa PGMI sangat baik. Sebanyak 21 mahasiswa karakter cinta ilmu dan rasa ingin tahunya masuk dalam kategori baik dan sangat baik. Hanya 3 mahasiswa dengan kategori kurang baik dan tidak ada mahasiswa yang tidak baik karakter Al-Hirș-nya. Dengan demikian dapat disebutkan bahwa mayoritas mahasiswa PGMI memiliki kecintaan terhadap ilmu yang tinggi. Hal ini diperkuat lagi dengan rasa ingin tahu yang besar sehingga mahasiswa rajin membaca, diskusi, serta mencari referensi dari berbagai sumber.

Hasil penelitian karakter Al-Hirs mahasiswa PGMI Fakultas Tarbiyah IPMAFA Pati dapat dilihat sebagai berikut:

\footnotetext{
${ }^{12}$ Jalaluddin Rakhmat, Psikologi.., hlm. 52
} 


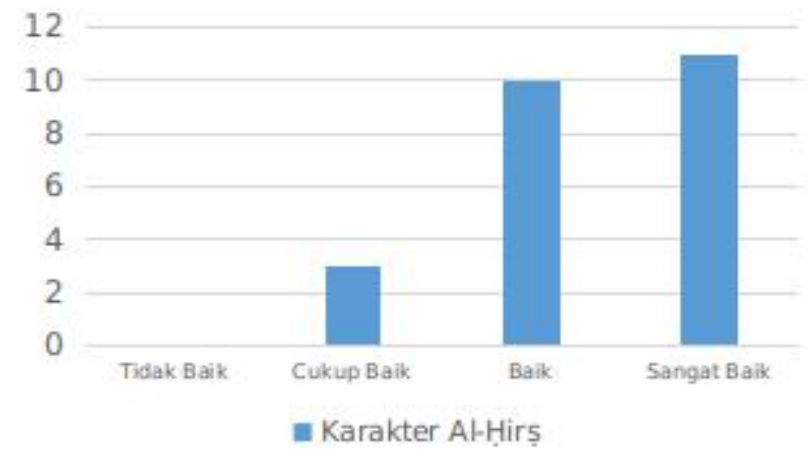

Gambar 2 Persentase karakter Al-Hirș mahasiswa PGMI Fakultas Tarbiyah IPMAFA

\section{c. Hubungan Kematangan Beragama dengan Karakter Al-Hirs}

Penelitian ini bertujuan mengetahui hubungan kematangan beragama dengan karakter Al-Hirș mahasiswa PGMI Fakultas Tarbiyah IPMAFA Pati. Data kematangan beragama dan karakter Al-Hirs yang diperoleh dianalisis menggunakan $r$ correlation Pearson untuk mengetahui hubungan antara kematangan beragama dengan karakter Al-Hirș mahasiswa PGMI Fakultas Tarbiyah IPMAFA Pati.

Berdasarkan uji prasyarat analisis yaitu uji normalitas dan uji linieritas menujukkan variabel yang diuji nilainya normal dan linier. Dengan demikian maka dapat dilakukan uji analisis data. Kemudian diuji apakah terdapat hubungan positif antara kematangan beragama dan karakter Al-Hirș dari mahasiswa PGMI.

Analisis data dilakukan dengan menggunakan teknik korelasi Product Moment dari Karl Pearson. Penelitian menggunakan bantuan SPSS versi 15.0 dengan melihat nilai Sig. untuk menentukan keputusan. Apabila nilai Sig. lebih kecil dari 0,05 , maka terdapat hubungan positif antara variabel bebas dan variabel terikat. 
Tabel 8 Tabel Uji Analisis Korelasi

Tabel Correlations

\begin{tabular}{|ll|r|r|}
\hline & kematangan \\
beragama & $\begin{array}{c}\text { karakter al } \\
\text { hirs }\end{array}$ \\
\hline kematangan & Pearson Correlation & 1 &, $416\left(^{*}\right)$ \\
beragama & Sig. (2-tailed) & 24 &, 043 \\
& $\mathrm{~N}$ &, $416\left(^{*}\right)$ & 24 \\
karakter al hirs & Pearson Correlation &, 043 & 1 \\
& Sig. (2-tailed) & 24 & 24 \\
& $\mathrm{~N}$ & & \\
&
\end{tabular}

* Correlation is significant at the 0.05 level (2-tailed).

Berdasarkan tabel di atas, menunjukkan nilai Sig. 0,043 lebih kecil dari 0,05 . Hal ini menunjukkan bahwa terdapat hubungan positif antara kematangan beragama dan karakter Al-Hirș mahasiswa PGMI Fakultas Tarbiyah IPMAFA Pati. Hasil skor kematangan beragama mahasiswa PGMI Fakultas Tarbiyah IPMAFA Pati menunjukkan tingkat kematangan beragama yang tinggi. Salah satu faktor yang menyebabkan kematangan beragama mahasiswa PGMI tinggi ialah latar belakang pendidikan yang mayoritas berasal dari pesantren. Hal ini diketahui dari wawancara dengan mahasiswa mahasiswa PGMI terkait pendidikan yang pernah diikuti sebelum kuliah.

\section{Pembahasan}

Toleransi, empati, disiplin diri, dan kebahagiaan hidup dapat diraih melalui kematangan beragama, bukan fanatisme dalam beragama. ${ }^{13}$ Mereka yang baru tahap mengetahui ajaran agama belum tentu memiliki kematangan dalam beragama. Bahkan apabila pengetahuan dan pemahaman agama tidak sesuai dengan ajaran agama yang sesunguhnya, berpotensi melahirkan fanatisme buta beragama. Dalam konteks keindonsiaan, fanatisme buta dapat mengancam

13 Natalya Khon dan Alla Kim, "From Religious Fanatic to Maturity in Faith: Cross-Confessional Tolerance as A Way to Understand Emotional Components of Others", Procedia Social and Behavioral Sciences, Vol. 236 Tahun 2016, hlm. 260 - 264 
keutuhan NKRI yang merupakan negara dengan tingkat keberagaman yang sangat tinggi.

Kematangan beragama merupakan sebuah proses panjang dalam membentuk karakter diri yang religius secara personal dan sosial. Proses tersebut melibatkan pengetahuan dan pemahaman agama yang baik, pembiasaan menjalankan perintah agama, hingga kontekstualisasi ajaran agama dalam perilaku sehari-hari. Ajaran agama dijadikan landasan berpikir, bersikap, dan berperilaku sehingga kematangan beragama tidak menjadikan pribadi ekslusif namun justru inklusif.

Lingkungan pesantren yang mendukung budaya religius memberikan pengaruh yang cukup signifikan bagi kematangan beragama. Rutinitas mengaji kitab yang dibimbing langsung oleh kiai atau santri senior dengan keilmuan agama yang mendalam serta pemantauan terhadap perkembangan santri selama 24 jam penuh mampu membentuk karakter khas santri yang religius dan haus ilmu. Nilai-nilai seperti teosentris, pengabdian, kearifan, kesederhanaan, kebersamaan, kemandirian, dan restu kiai yang sangat erat sekali bagi kalangan pesantren. ${ }^{14}$ Maka tidak mengherankan apabila mahasiswa yang mayoritas pernah mengenyam dunia pendidikan pesantren memiliki tingkat kematangan beragama yang tinggi.

Untuk mengetahui ciri-ciri orang yang beragamanya matang digunakan konsep yang dipaparkan Gordon W. Allport dikutip Ismail. ${ }^{15}$. Ciri-ciri kematangan beragama memiliki kriteria sebagai berikut:

a) Differensiasi yang baik, orang yang matang beragamanya dalam ciri ini ia mengimani kuat agama yang dianutnya tapi di sisi lain ia juga mau belajar kepada siapapun termasuk kepada pemeluk agama lain.

${ }^{14}$ Hariadi, Evolusi Pesantren, Yogyakarta: LkiS, 2015, hlm. 66-70.

${ }^{15}$ Roni Ismail, Pembelajaran Agama Islam terhadap Wanita Lanjut Usia di Panti Sosial, JIPSA, Vol. 16, No. 20 tahun 2007, hlm. 4-5 
b) Motivasi kehidupan yang dinamis, orang yang memiliki kematangan beragama menjadikan agama sebagai tujuan dan kekuatan untuk mengatasi setiap persoalan hidup.

c) Pelaksanaan secara konsisten dan produktif, orang yang beragama matang akan berperilaku sesuai dengan nilai-nilai ajaran agamanya secara konsisten dalam kehidupan sehari-harinya.

d) Pandangan hidup yang komprehensif, orang yang memiliki kematangan beragama maka ia mampu menerima perbedaan pemikiran dan pendapat dengan orang lain. Dengan demikian jika terdapat konflik kekerasan maka hal tersebut bukan bagian dari orang yang beragama matang.

e) Pandangan hidup yang integral, orang yang beragama matang senantiasa menyatukan atau menyelaraskan antara ajaran agama dengan aspek lain dalam kehidupannya.

f) Heurisrik, orang yang memiliki kematanggan beragama akan selalu berusaha untuk meningkatkan pemahaman dan penghayatan dalam beragama.

Kematangan beragama dapat diklasifikasikan menjadi tiga, yaitu pertama yang berhubungan dengan akidah dan dekat dengan Tuhan. Kedua ibadah, taat beribadah, beribadah secara sukarela berdasarkan kesadaran bukan karena paksaan hal ini lebih karena faktor internal. Ketiga berhubungan dengan perilaku, tidak mudah putus asa, senantiasa bersyukur, toleran, mudah memaafkan, dan terbuka.

Ketiga hal tersebut secara sederhana dapat diterangkan sebagai hubungan yang baik antara manusia dengan Allah SWT serta manusia dengan manusia dan alam sekitar. Maka kematangan beragama tidak hanya dilihat dari seberapa baik manusia beribadah kepada Allah, namun juga dilihat dari bagaimana hubungan manusia dengan manusia lainnya dan alam sekitar. Terminologi ini selaras dengan keimanan dalam konsep Islam dimana iman bukan hanya meyakini dalam hati tetapi juga melalui perkataan dan perbuatan yang sesuai dengan keimanannya. 
Sementara karakter Al-Hirș dapat diartikan sebagai keingintahuan terhadap ilmu dan pengetahuan yang tinggi sehingga menjadi motivasi belajar yang tidak terkikis waktu dan usia. Secara terminologi, Al-Hirș yaitu usaha mendapatkan sesuatu dengan sungguh-sungguh untuk memenuhi kebutuhannya. Usaha ini tidak terlepas dari dorongan rasa ingin tahu yang besar akan sesuatu sehingga besar pula harapan untuk mengetahui dan mewujudkannya. Semakin banyak ilmu yang didapatkan bukan semakin puas namun justru merasa semakin miskin ilmu sehingga harus terus belajar.

Pembelajar yang aktif dan selalu ingin mengembangkan diri salah satu faktornya ialah besarnya rasa ingin tahu. ${ }^{16}$ Lingkungan memberikan pengaruh besar terhadap rasa ingin tahu yang diasosiasikan dengan pencarian sensasi yang mendorong seseorang termotivasi untuk mencari pengetahuan atau pengalaman. ${ }^{17}$ Kondisi lingkungan sekitar memberikan pengaruh signifikan terhadap rasa ingin tahu seseorang. Maka dari itu, pembentukan lingkungan yang kondusif akan semakin meningkatkan rasa ingin tahu akan berbagai pengetahuan dan pengalaman.

Lingkungan pesantren memiliki keunikan yang mampu meningkatkan rasa ingin tahu santrinya. Pembelajaran terhadap kitab klasik yang kemudian dijelaskan dengan sangat baik oleh kiai secara kontekstual, terbukti memacu santri untuk berpikir dan memproses pengetahuan dengan pengalamannya. Pesantren yang disebut sebagai sub sistem oleh Gusdur menampilkan budaya akademis yang dinamis. Mereka yang mengajar kitab kuning tidak menutup diri untuk berdiskusi dan melayani pertanyaan dari santri. Terkadang diskusi di tengah pengajian dapat berjalan sangat lama karena menariknya topik yang dibahas.

${ }^{16}$ Steven Raharja, Martinus Ronny Wibhawa, dan Samuel Lukas, Mengukur Rasa Ingin Tahu, A Journal of Language, Literature, Culture, and Education POL YGLOT, Vol. 14 No. 2 Juli 2018, hlm. 151-164

${ }^{17}$ Jonathan Rowson, The Power of curiosity: How linking inquisitiveness to innovation could help to address our energy challenges, London: RSA Social Brain Centre, 2012 hlm. 36 
Selain lingkungan, Stokoe berpendapat bahwa pendorong yang menjadikan seseorang sebagai pembelajar sepanjang hayat adalah rasa ingin tahunya, yakni kemampuan mendasar yang harus dimiliki bagi segenap pembelajar. ${ }^{18}$ Rasa ingin tahu yang besar juga menyebabkan individu berusaha mengumpulkan informasi baru dan penting untuk aktualisasi diri dan memaksimalkan potensi diri. ${ }^{19}$ Berkembangnya potensi diri ditentukan seberapa besar rasa ingin tahu dan tekad untuk menemukan pengetahuan dan pengalaman baru.

Menjaga dan mengembangkan karakter rasa ingin tahu akan meningkatkan daya ingat seseorang. Daya ingat berperan penting dalam menyimpan dan menggali informasi yang telah didapatkan sebelumnya. ${ }^{20}$ Daya ingat yang baik memberikan kemudahan untuk mengembangkan pikiran dan memperluas wawasan karena mampu mensinergikan antara informasi sebelumnya dengan berbagai pengetahuan dan pengalaman yang baru dan akan dialami.

Untuk meningkatkan karakter Al-Hirș dalam belajar dapat didukung melalui beberapa cara. Pertama, keseriusan yakni niat yang kuat dan tekun dalam menuntut ilmu. Tidak ada niat sedikitoun menuntut ilmu hanya untuk main-main. Kedua, intensif belajar, untuk melakukannya dibutuhkan daya juang tinggi dan mental yang tangguh dalam menuntut ilmu. Tidak ada ulama atau ilmuwan yang mendapatkan ilmu secara instan, namun ada proses yang harus dilalui yakni belajar secara terus-menerus dibarengi dengan berdoa pada yang Maha Memiliki Ilmu. Ketiga, cita-cita yang tinggi, tujuan utama dalam menuntut ilmu harus diluruskan sejak awal. ${ }^{21}$ Cita-cita yang tinggi akan memotivasi untuk terus belajar dan berguru kepada siapapun.

\footnotetext{
${ }^{18}$ Robert Stokoe, Curiosity, a Condition for Learning, The International Schools Journal, Vol. 32 No. 1 Tahun 2012, hlm. 63-66.

19 Angeline Hosana Zefany Tarigan dan Indra Prapto Nugroho, Rasa Ingin Tahu Remaja Ditinjau dari Keinginan untuk Mengaktualisasikan Diri dalam Ruang Lingkup Sekolah, Jurnal Bimbingan dan Konseling Ar-Rahman, Vol. 5 No. 1 Tahun 2019, hlm. 24-28

${ }^{20}$ Shannon McGillivray, Kou Murayama, \& Alan D. Castel, Thirst for Knowledge: The Effects of Curiosity and Interest on Memory in Younger and Older Adults, Psychology and Aging, Vol. 30 No. 4 Tahun 2015, hlm. 835-841

${ }^{21}$ Syekh Ali bin Sayyid Muhammad Syarif Al-Jurjani, At-Ta'rifat, Beirut: Dar Al- Fikr, th.
} 
Berdasarkan ilmu psikologi, karakter Al-Hirș dapat dilihat dari konsep tentang rasa ingin tahu. Reio dan Callahan mendefinisikan rasa ingin tahu sebagai keadaan gairah emosional yang disebabkan oleh konflik konseptual atau ketidakpastian yang menginduksi perilaku eksplorasi dan pencarian informasi untuk meringankan ketidakpastian. ${ }^{22}$ Rasa ingin tahu akan membangun pemikiran dan sikap kritis mahasiswa. Ciri-ciri dari rasa ingin tahu yang tinggi antara lain minat atau tertarik mencari kebaruan, keterbukaan, terhadap pengalaman baru, menaruh perhatian pada hal-hal atau pengalaman baru, melihat berbagai hal atau topik sebagai hal-hal menarik, menjelajah dan berusaha menemukan sesuatu.

Data penelitian menunjukkan karakter Al-Hirș mahasiswa PGMI sangat baik. Rasa ingin tahu dan motivasi untuk terus belajar menjadi sebab baiknya karakter Al-Hirș. Hal ini nampak dari kemauan mahasiswa PGMI belajar sendiri dengan membaca literatur yang mendukung keilmuan dan mampu mengembangkan wawasan. Setidaknya motivasi dan ketertarikan belajar hal-hal baru serta lintas disiplin ilmu mulai terbentuk dan terus berkembang.

Keaktifan mahasiswa PGMI dalam diskusi di kelas menjadi indikator lain karakter Al-Hirș yang baik. Bahkan organisasi kemahasiswaan PGMI menambah porsi diskusi dengan menjadwalkan diskusi tambahan di luar diskusi kelas. Selain aktif berdiskusi juga terbuka untuk saling berbeda pendapat tanpa ada keinginan untuk saling menjatuhkan atau hanya sekedar memenangkan sebuah perdebatan. Mahasiswa aktif didorong oleh rasa ingin tahunya yang besar.

Hasil penelitian menunjukkan hubungan yang positif antara kematangan beragama dengan karkater Al-Hirș mahasiswa PGMI. Semakin tinggi atau semakin matang tingkat keberagamaan mahasiswa, semakin tinggi pula karakter Al-Hirș mahasiswa tersebut. Hubungan di antara dua variabel sangat signifikan

22 TG. Reio \& JL Callahan, Affect, Curiosity, and Socialization-related Learning a Path Analysis of Antecedents to Job Performance, Journal of Business and Psychology, Vol.19 No. 1 Tahun 2004, hlm. 97 
dengan demikian hipotesis penelitian ini diterima. Yakni terdapat hubungan yang signifikan antara kematangan beragama dengan karakter Al-Hirș mahasiswa PGMI Fakultas Tarbiyah IPMAFA Pati.

Keterbatasan penelitian ini adalah sampel penelitian yang tidak begitu banyak serta hanya satu program studi saja. Hal ini berakibat pada kesimpulan dari penelitian ini belum bisa digeneralisasi untuk seluruh mahasiswa IPMAFA Pati. Namun cukup untuk menunjukkan hubungan yang signifikan antara kematangan beragama dengan karakter Al-Hirș. Akan tetapi keterbatasan ini dapat menjadi langkah awal untuk menindaklanjuti dalam penelitian selanjutnya.

IPMAFA Pati sebagai perguruan tinggi Islam yang berbasis pada nilai-nilai pesantren memiliki nilai khas pesantren yang terangkum dalam NDSA. Internalisasi dan eksternalisasi nilai-nilai tersebut akan mampu melahirkan manusia yang shalih dan akram. Penelitian ini menunjukkan bahwa salah satu karakter dalam NDSA yakni Al-Hirs berhubungan erat dengan kematangan beragama sekaligus mampu memberikan semangat kepada mahasiswa untuk terus belajar.

\section{SIMPULAN}

Berdasarkan hasil penelitian yang dilakukan maka dapat diambil simpulan bahwa, antara kematangan beragama dengan karakter Al-Hirș mahasiswa PGMI Fakultas Tarbiyah IPMAFA memiliki hubungan yang signifikan dan positif. Arah hubungan korelasi di antara dua variabel cukup tinggi. Sehingga semakin tinggi kematangan beragama maka semakin baik pula karakter Al-Hirș mahasiswa PGMI. Dengan demikian, kematangan beragama mahasiswa PGMI Fakultas Tarbiyah IPMAFA Pati memberikan pengaruh yang signifikan terhadap karakter Al-Hirș, rasa ingin tahu, dan semangat untuk terus belajar. Implikasi dari ini ialah sikap disiplin 
mahasiswa dalam mengikuti pembelajaran dan diskusi di kelas yang akan mampu memacu pengembangan diri mahasiswa PGMI.

Terakhir, tidak lupa ucapan terima kasih kepada Lembaga Penelitian dan Pengabdian kepada Masyarakat (LPPM) IPMAFA Pati atas bantuan moril dan materiil sehingga penelitian ini berjalan dengan baik. 


\section{DAFTAR PUSTAKA}

Al-Jurjani, Syekh Ali bin Sayyid Muhammad Syarif, At-Ta'rifat, Beirut: Dar Al- Fikr, tth

Arikunto, Suharsimi, Prosedur Penelitian Suatu Pendekatan Praktik, Jakarta: Rineka Cipta, 2014

Faruq, Asrul, dan M. Sofyan Alnashr, "Implementasi Strategi Pembelajaran Edupreneurship Berbasis Multiple Intelligences", Jurnal Islamic Review, Vol. 6 No. 2 Th. 2017, hlm. 195-210, DOI: https://doi.org/10.35878/islamicreview.v6i2.129

Hadi, Sutrisno, Metodologi Research 2, Yogyakarta: Andi Offset, 2004

Hidayat, Komaruddin, Agama Punya Seribu Nyawa, cet. II, Jakarta: Noura Books, 2012

Ismail, Roni, "Pembelajaran Agama Islam terhadap Wanita Lanjut Usia di Panti Sosial", JIPSA, Vol. 16, N. 20. 2007

Jalaluddin, Psikologi Agama, Jakarta: PT. Grafindo Persada, 2016

James, Wiliam, The Varieties of Religious Experience: A Study in Human Nature, New York: Modern Library, 1958

McGillivray, Shannon; Kou Murayama, \& Alan D. Castel, Thirst for Knowledge: The Effects of Curiosity and Interest on Memory in Younger and Older Adults, Psychology and Aging, Vol. 30 No. 4 Tahun 2015

Musfah, Jejen, Pendidikan Holistik: Pendekatan Lintas Perspektif Islam, Jakarta: Kencana, 2012

Raharja, Steven, Martinus Ronny Wibhawa, dan Samuel Lukas, Mengukur Rasa Ingin Tahu, A Journal of Language, Literature, Culture, and Education POL YGLOT, Vol. 14 No. 2 Juli 2018

Rakhmat, Jalaluddin, Psikologi Agama; Sebuah Pengantar, (Bandung: Mizan, 2003)

Reio, TG \& JL Callahan. "Affect, Curiosity, and Socialization-related Learning a Path Analysis of Antecedents to Job Performance", Journal of Business and Psychology, Vol.19 No. 1 Tahun 2004.

Rizqiyah, Umi, Analisis Kematangan Beragama Orang Tua yang Berusia 40-49 Tahun dalam Pembinaan Akhlaq Anak (Studi Kasus di Lingkungan Masyarakat Desa Grogol Kec. Dukuhturi Kab. Tegal), Skripsi, Semarang: FITK UIN Walisongo, 2017

Rowson, Jonathan, The Power of curiosity: How linking inquisitiveness to innovation could help to address our energy challenges, London: RSA Social Brain Centre, 2012

Statuta Institut Pesantren Mathali'ul Falah Pati Tahun 2015 pasal 38

Stokoe, Robert, Curiosity, a Condition for Learning, The International Schools Journal, Vol. 32 No. 1 Tahun 2012 
Sugiono, Metode Penelitian Kuantitatif, Kualitatif, dan Kombinasi (Mixed Methods), Edisi Keempat, Bandung: Alfabeta, 2013

Tarigan, Angeline Hosana Zefany, dan Indra Prapto Nugroho, Rasa Ingin Tahu Remaja Ditinjau dari Keinginan untuk Mengaktualisasikan Diri dalam Ruang Lingkup Sekolah, Jurnal Bimbingan dan Konseling Ar-Rahman, Vol. 5 No. 1 Tahun 2019

Wahyuni, Ida Windi, "Hubungan Kematangan Beragama dengan Konsep Diri", Jurnal Al-Hikmah, Vol. 8 No. 1, Tahun 2011

Yulika, Apni, dan Kiki Cahaya Setiawan, "Kematangan Beragama dengan Perilaku Pacaran pada Santri MA di Pondok Pesantren Modern Al-Furqon Prabumulih", Jurnal Psikologi Islami, Vol. 3 No. 1 Tahun 2017

Zaenurrosyid, A., Pengaruh Pondok Pesantren terhadap Kehidupan Sosial Masyarakat Desa Kajen Kec. Margoyoso Kab. Pati, Jurnal Islamic Review, Vol. VII No. 1 Tahun 2018,

DOI: https://doi.org/10.35878/islamicreview.v7i1.133 